SZELI KATALIN

\title{
Információs- vagy tudástársadalom?
}

Farkas János

$\mathbf{N}$

$\mathbf{F}$

\section{Szerzői információ:}

0

Kissné Szeli Katalin

1998-ban diplomázott az ELTE magyar-francia szakán. 1999-tốl a BME-UNESCO Információs Társadalom- és Trendkutató Központ (ITTK) munkatársa. Az Európai Unió ESIS (European Survey of Information Society) programjában a hazai információs társadalom projektek szemlézője, a kérdốives adatfeldolgozás vezetôje, illetve a promóciós jelentések szerzője. 2002-tốl az ITTK Kutatási Jelentés c. folyóirat szerkesztổje és az ITTK Privacy hírlevelének olvasószerkesztője.

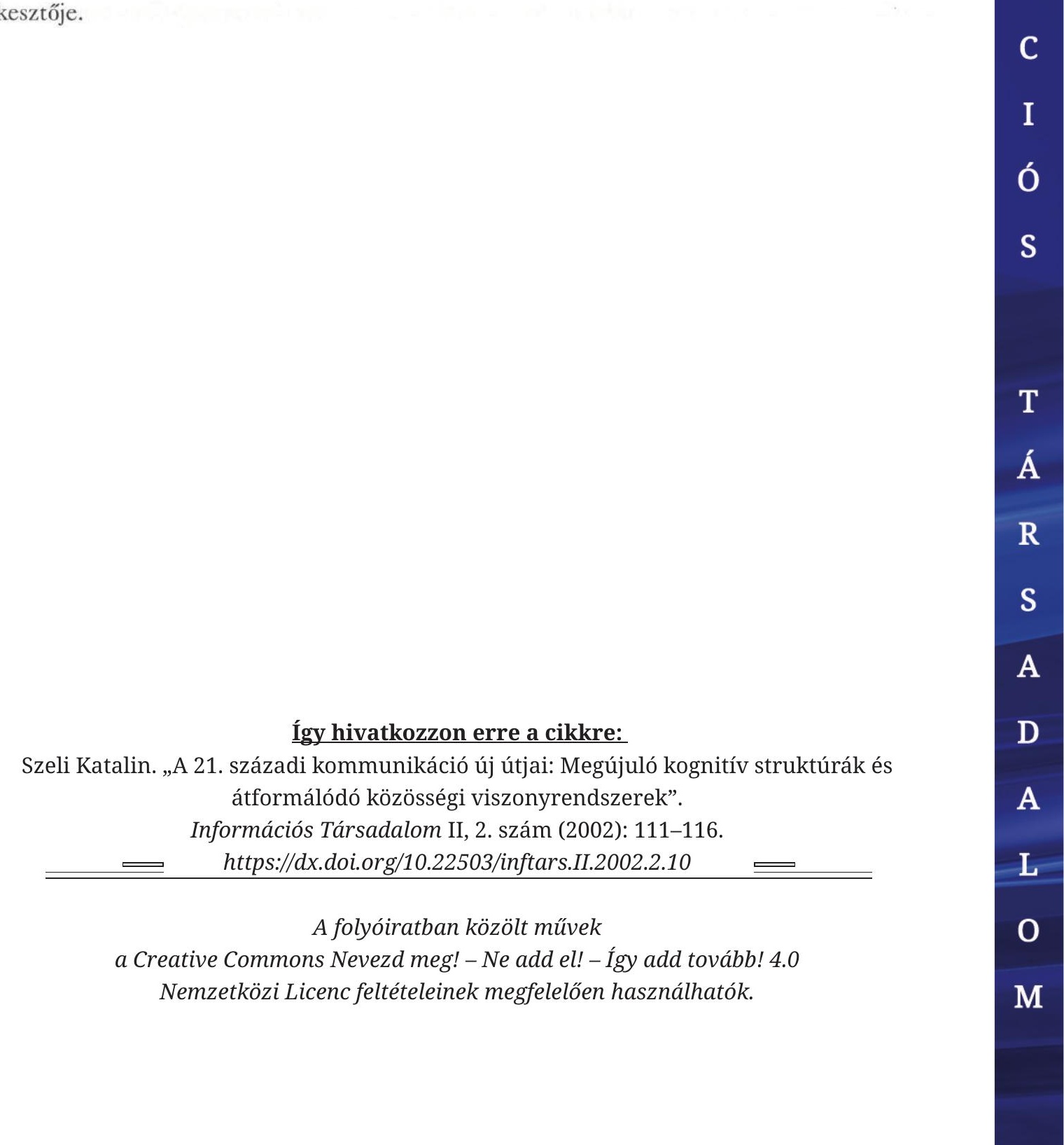


Szeli Kat a lin

\title{
A 21. századi kommunikáció új útjai
}

\author{
Megújuló kognitív struktúrák és átformálódó \\ közösségi viszonyrendszerek
}

Újabb állomásához érkezett az a - 2001 januárja óta zajló - interdiszciplináris társadalomtudományi kutatás ${ }^{1}$, melyet a Magyar Tudományos Akadémia koordinál és a Westel Mobil Távközlési Rt. támogat. A kutatási eredményekrốl tudósító, múlt évben rendezett két konferenciát és tanulmánykötetet (melyekról e folyóirat induló száma recenzált) május 24-25-én - e program keretében első ízben - egy nemzetközi konferencia követte $A$ 21. sáázadi kommunikáció új útjai címmel, vezetố magyar tudósok és világhírû brit, svéd, amerikai, német és osztrák kutatók közremúködésével. Az itt elhangzott előadások több újabb tanulmány kíséretében ez év őszén fognak megjelenni a Mobil közösség, mobil megismerés címú kötetben, magyar, német és angol nyelven.

Az előadók számos tudományág eszközrendszerét és megközelítési módjait felhasználva tettek kísérletet a modern kommunikációs technológiáknak - az élet gyakorlatilag minden területét átalakító - hatásai leírására és elemzésére: felvetődtek kommunikációelméleti, számítástudományi, episztemológiai, pszichológiai, orvostudományi, nyelvtudományi, politikaelméleti, közgazdaságtani, tudománytörténeti és szociológiai kérdések. Jelen írás - szem előtt tartva e számnak a rendszer/evolúció/kogníció fogalmakkal meghatározott tematikus jellegét - azon tanulmányoknak ${ }^{2}$ az összegzésére vállalkozik, melyek a kommunikációs technika fejlődésének folyományait egy újabb evolúciós szint lehetséges okaként és sajátosságaként próbálják megragadni. Ezek a tanulmányok a legalapvetőbb kérdéseket - a megismerési-gondolkodási folyamatokat és a közösségi kapcsolatok szervezôdését - taglalják.

A mai információs technológiákkal elterjedô új közlésmódok és a megismerési rendszerek kapcsolatával foglalkozik Pléh Csaba. Kiindulópontja a kognitív pszichológia egyik vezetô felismerése, miszerint a megismerést ún. kognitio architektúrák jellemzik, azaz olyan gondolkodási szerkezetek, amelyek meghatározzák információkezelési módjainkat. A teljes emberi architektúrának van egy ősi, biológiai, évmilliók alatt kialakult rétege és egy, a kulturális fejlődés során létrejött, másodlagos szintje. Pléh az architektúrák változékonyságával kapcsolatosan azoknak a véleményét osztja - hivatkozva itt elsôsorban Merlin Donald koncepciójára ${ }^{3}$-, akik feltételeznek egyfelól rögzült, stabil rendszereket, másfelől olyan másodlagos megismerési struktúrákat, amelyeket a kultúra és a közlési eszközök változása folyamatosan alakít, módosít. A kultúra gondolkodást formáló erejét alátámasztandó kiemeli a nyelv kialakulását, s Nyíri Kristóf gondolatrendszerének egyik központi tézisét idézi: „Az első prioritás nem a beszéd volt... A csoportként való összekapcsolódás... s azoknak a társas mintáknak a kialakítása volt a cél, amelyek a fajnál támogatják ezt a kölcsönösséget és kötôdést... A nagy vízválasztó az emberi evolúcióban nem a nyelv volt, hanem a kognitív közösségek elsôdleges kialakulása."

Rátérve a mai információs technológia okozta architekturális változások ismertetésére, Pléh elsőként két ellentétes irányú, egyidejú folyamatra hívja fel a figyel- 
met. Egyfelől, az eszközök használóinál, érvényesül egy kívülről befelé mutató hatás, azaz az új típusú kommunikáció megváltoztatja az emberi gondolkodást - többek között kevésbé lineárissá és képibb jellegûvé (ezt az aspektust fejtegeti bővebben Nyíri lentebb ismertetett írásában) teszi. Másfelől, a modern közlési formák kereteinek megteremtốinél, egy belülrốl kifelé irányuló hatás is múködik, hiszen ôk éppen a gondolkodási módokból kiindulva alkotják meg az új technológiát. Tehát nemcsak a kommunikáció alakítja gondolkodásunkat, hanem gondolkodási módjaink ismerete révén kifejezési rendszereinket is át tudjuk alakítani.

Az új közlési közegek számos vonatkozásban növelik az aktivitást, folytatja a szerző, példaként említve a hálózati keresést mint igazi aktív, kezdeményező folyamatot. (Ha már az Internetnél tartunk, folytathatnánk a sort az e-mailek küldésével, a chathasználattal, a fórumokba való beírással, hiszen ezek a felületek lehetôséget adnak az azonnali és akár sokakat megszólító véleménynyilvánításra és információtovábbításra, s emiatt ösztönzően hathatnak. Bár nem szabad elfeledkeznünk a jelenség paradox jellegéról sem: az e-mailek helyettesíthetnek személyes találkozásokat, és elképzelhetô, hogy pl. a politikai fórumba való írás kiválthatja a tüntetésen való részvételt. Tehát a virtuális aktivitás akár visszaszoríthatja a valós cselekvésekre épülő aktivitást.)

Pléh figyelmeztet arra, hogy a Weben megszületố virtuális tereknek nemcsak pozitív - a szabadságot jelentő - tartalma van. Felvetôdik a fantázia uralta architektúra veszélye, létrejöhetnek „elektronikus Don Quijoték”. Ez a probléma nem új - teszi hozzá -, hiszen Don Quijote a könyvnyomtatás korának virtualitása áldozata, de napjainkban megnôtt a virtualitások aránya, ezért a realitáskontroll elvesztésének veszélye sokkal erősebben fenyeget. Egy újabb - s tegyük hozzá: sokkal szélesebb kört érintő - kihívást jelent az állandó elérhetőség, vagy ahogy Hrachovec, egy szintén késốbb tárgyalandó szerzố fogalmaz, az állandó jelenlét. Ennek kapcsán Pléh az idôgazdálkodás felborulását: a munka és magánélet összefolyását, a kötelezô és állandó nyitottság miatti túlterheltséget és az új tudáselemek megszerzésére és azok használatára fordított idő aránytalanságait emeli ki.

Egy újabb fontos architekturális változást jelez a készségek szerepének megnövekedése az explicit tudásokhoz képest, hiszen az emlékezetet már nemcsak a könyvek, hanem sokkal könnyebben és gyorsabban hozzáférhető külső tárak is segítik. A mai ember a tanulás-tanítás új formáihoz is kénytelen alkalmazkodni. A gyorsan változó környezetben nemcsak az élethosszig tartó tanulás jelenik meg, hanem a horizontális tanítás (kortársak tanítják egymást) és az ellenirányú vertikális tanítás is (fiatalok tanítják az idôsebbeket).

Végül Pléh utal arra, hogy az új kommunikációs formák hatással vannak az alapvetôen kétféle gondolkodási mód - antropomorf elbeszélő és személytelenítô elméleti -'érvényesülése közötti arányokra, pontosabban eltolódás figyelhetô meg az előbbi javára.

Valójában Nyíri Kristóf is a kognitív architektúra egyik sajátosságáról beszél, amikor tanulmányában a képi gondolkodás és a mobil kommunikáció kapcsolatait kutatja, csak ô ellentétes irányból közelíti meg a kérdést, és mondanivalóját a közösség vonatkozásaira is kiterjeszti. Számos filozófiatörténeti elốzményre támaszkodva hangsúlyozza, hogy a gondolkodás ősi, eredeti anyagát a képek jelentik, és mivel hasonlítanak az általuk megjelölt tárgyakra és tényekre, kiválóan alkalmasak az információ közvetítésére. Azonban csak most születtek meg azok az eszközök, a számítógépes grafi- 
ka és újabban az MMS - a multimédiás üzenetküldés -, amelyek alkalmasak a képek gyors, könnyú elóállítására, sokszorosítására és továbbítására. Az ô látásmódja szerint tehát nem a kultúra, a kifejezési módok alakítják a gondolkodást, hanem az ember fejleszti ki azokat a kommunikációs eszközöket, amelyek a legadekvátabb módon felelnek meg gondolkodásának. A filozófus hozzáteszi, hogy a képi kommunikáció önmagában nem, csak a szavak kíséretével lehet sikeres. Nyíri a kommunikációs technológiák fejlődésében mérföldkônek tekinti az MMS bevezetését, amely alkalmas fényképek készítésére és továbbküldésére, rajzok, képek szerkesztésére, valamint ezek szöveggel ötvözésére és elküldésére. Mivel ez az eszköz könnyen hordozható és a segítségével elkészített képek nem igényelnek rajztehetséget, úgy véli, hogy segítségével a képek alkotása és terjesztése egyszer közönséges, mindennapi készséggé fog válni. A mobil kommunikáció vizuális nyelvvel történő gazdagításához kettôs feladatot kell megoldani, teszi hozzá: egyrészt egységes és sokrétû konvenciókat kell bevezetni, másrészt ki kell aknázni a képi hasonlóságban mint természetes jelentésközvetítő elemben rejlő lehetőségeket. Végül kitér a képi kommunikáció és az MMS közösségformáló szerepére is. Egyfelől, a képek kapcsolatot teremtenek a különböző nyelveket beszélók között, sốt, a közös nyelvet bírók között is hatékonyabban alkotnak közösséget. Másfelől, az MMS jelentősége abban rejlik, hogy nem pusztán képeket továbbít, hanem hangot, grafikus és írásos információkat komplementer módon, egyidejúleg képes közvetíteni. Nyíri konklúziója az - mivel álláspontja szerint a közösségeket éppen az olyan típusú kommunikáció kovácsolja egybe, amely a különbözô csatornákon közvetített információk komplementaritását mutatja -, hogy a multimédiás üzenetküldés a közösségi kohézió erősödéséhez fog vezetni.

Pléhhez hasonlóan Herbert Hrachovec is a gondolkodási folyamatokra összpontosít, ezen belül pedig elsôsorban a megismerési mechanizmusban tapasztalható változások - melyeket nem csak a legújabb kommunikációs technológiáktól, hanem korábbról, az elsố telekommunikációs eszközök elterjedésétôl eredeztet - kötik le figyelmét. Írásában a „táv-jelenlét” fogalmának és a média által sokat hangoztatott szlogennek, miszerint „a modern technológia eltörli az idő és a tér korlátait”, kísérel meg a mélyére nézni.

A mindenütt való egyidejú jelenlét paradoxonának feloldásához a hagyományos episztemológia néhány alaptételének újragondolását tartja szükségesnek. Ebben a paradigmában a tudás megszerzésének az előfeltétele az érzéki benyomás, amelyet a befogadó közvetlen közelében keletkezố ingernek kell kiváltania. A technológia mint például az elektromosság, a telefon vagy a számítógépes hálózatok - azonban okokozati láncolatok révén képes távoli behatásokat közvetíteni az emberhez. A szerző emlékeztet a kognitív paradoxon néven ismertté vált jelenségre: a hagyományos ismeretelméletị forgatókönyv a gyertya meggyújtását kísérố kognitív folyamatot modellezi - mondja -, viszont a villanykapcsoló meggyújtásának feldolgozásával már nem tud megbirkózni. Az elektromosság elterjedése, a tér gyors fizikai folyamatokkal való áthidalása azonban önmagában még nem kérdôjelezi meg a tudásról alkotott hagyományos fogalmat. Gondolatmenetét az episztemológiai leírások szemiotikai megalapozottságára való utalással folytatja. Eszerint az információkat jelek hordozzák: ilyen jelek a kimondott szavak, szövegek, képek. A jeleket, annak ellenére, hogy potenciálisan távoli tartalmakat közvetítenek, korábban az érzéki megismerés közvetlen tartományába ágyazták be, mivel nem volt lehetôség távolról, valós időben, ok-okozati 
mechanizmusok által történó megjelenítésükre. A modern médiumok esetében gondoljunk például a televízióban sugárzott élő riportra - éppen ez történik. A táv-jelenlét, az azonnali tele-közvetítés jelensége a klasszikus episztemológia felülvizsgálatához vezet. A telekommunikáció korának embere abban a skizoid állapotban találja magát, hogy felborult az időbeli és a térbeli jelenlét közötti szimmetria, mely szimmetriát a nyelvek is tükrözik: ugyanazt a kifejezést, a „jelen”-t kínálják fel az adott pillanatra (,jelen időpont”) és az abban való részvétel (,jelenlét”) megjelölésére mivel a térbeli tárgyak érzékelése eredetileg egybeesett azok tényleges jelenlétével. A táv-jelenlét ugyanis azt jelenti, hogy távoli terek résztvevôi egyszerre osztozhatnak egyetlen pillanatban: az idôbeli jelenlét tehát érvényben marad, de a térbeli jelenlét megszűnik, illetve az „egy virtuális környezetben való tartózkodás”-sá alakul át. A közvetített jelenlét napjainkban egyre súrúbbé válik (egyre többen használnak mobiltelefont és Internetet) - hamarosan az egyidejúség és a mindent áthatás együttesen érvényesül majd. Milyen felismerésekhez vezethetik a telefon, a rádió, a TV és az Internet által kínált szimbólumrendszerek a megismeréstudományt? Hrachovec szerint az egyik fontos szempont, hogy a jelkészletek bárhol és bármikor azonnal hozzáférhetőek, valamint alapvető fontossággal bír, hogy a telekommunikációs eszközök nem közvetlen jeleket továbbítanak, hanem csak egy leképezését az eredeti jelnek. Bár a szerzố nem mondja ki, de következtetései implikálják, hogy a jelek közvetettsége miatt az információfeldolgozási folyamatba egy új elem iktatódott be. Ez a bizalom, vagy más megközelítésből a kételkedés - hiszen a közvetített információk autenticitása mindig kétséges. A bizalmi dimenzió bevezetésének létjogosultságát tovább erôsíti az olyan média-technológiák elterjedése - melyekre a szerzô is utalást tesz -, amelyek képesek a képet és a hangot manipulálni.

Robin Dunbart is az új kommunikációs technológia és az agyi múködések kapcsolata foglalkoztatja, de ố egyrészt a biológiai evolúcióból kiindulva közelíti meg a kérdést, másrészt a szociális kapcsolatok jellegét és kiterjeszthetőségének problémáját tartja szem elôtt. Egy elterjedt hipotézisre hivatkozva áttekinti a szociális agy kialakulásának történetét a fôemlősöktôl kezdve, amit az agy méretének növekedésével, közelebbrôl a neokortex - az agynak a gondolkodási funkciókért felelős része - nagyságával hoz egyszerú, lineáris összefüggésbe. Tehát egy fôemlősfaj akkor válik képessé nagyobb szociális csoportokban élni, ha ehhez megfelelő méretû neokortexet fejlesztett ki. A fejlődési vonulat végén álló embernek neokortexe alapján körülbelül 150 fős csoportokban kellene élnie - amit a tények is jól alátámasztanak, ha a vadászgyújtốk csoportnagyságára, vagy akár azoknak az embereknek a számára gondolunk, akikkel az egyén a mai, információs társadalomban valóban kapcsolatban áll, teszi hozzá Dunbar. Arra a következtetésre jut, hogy az ember - kognitív rendszerének gátjai miatt - csak korlátozottan képes hasznosítani az új technológiákat, azaz hiába adottak az eszközök, a szociális hálózat ma sem tágítható ki a körülbelül 150 fős méreten felül. E korlátok hátterét is igyekszik feltárni az adott intenzitású kapcsolatok feltétele az egymásról való tudás és a erre épülő bizalom - mindezt pedig az együtt eltöltött idố mennyisége határozza meg. A fốemlősök esetében a szociális kapcsolattartás eszköze a tisztálkodás volt, amit az embernél a nyelv vált fel, lehetôvé téve az egyszerre több egyénnel való interakciót és a közösség tagjairól való információcserét - s ezzel a megnövekedett csoportméretet. A posztindusztriális környezet kitágítani ugyan nem tudja kapcsolataink körét - illetve csak azoknak a kapcsolatoknak a szá- 
mát nem növeli, amelyek valódi megismerésen és bensőséges kontaktuson alapulnak, pontosít a szerzô -, arra viszont lehetőséget ad, hogy az eddiginél lényegesen nagyobb földrajzi területre terjesszük ki. Kiemel egy másik, az elektronikus kommunikációval járó jelenséget is: annak veszélyét, hogy mivel hiányoznak a megértést segítô nonverbális jelek, az egyén helytelenül értelmezheti a partner szándékát, üzenetének tartalmát, valamint ôszinteségét is.

Dunbar kitér a „potyázás” problémájára, ami a - fennmaradás érdekében kötött, és a közvetlen egyéni célokról való részleges lemondással járó - kooperatív társadalmi alku megszegését jelenti. A nyelv hatékony eszközöket kínál a csalások elleni küzdelemhez a potyázókról való információcsere és a szabályszegốk verbális megrovása formájában. A gondolatmenet itt megszakad, pedig egyik természetes leágazása lehetne, hogy az információáramlást felgyorsító modern technológia megkönnyítheti a rend fenntartását - gondoljunk a mobiltelefon-beszélgetésekre, vagy méginkább az egy-egy közösséget összetartó levelezólistákra, mely felületeken hatékonyan, ráadásul a kínos személyességet elkerülve lehet a szabálysértésekre felhívni a figyelmet.

Dunbar rámutat a kommunikációs technológia innovatív hasznosításának jelenségére is, s ennek magyarázatát az eredeti funkciók kiaknázhatóságának korlátaiban látja. Példaként egy vizsgálattal is alátámasztott megfigyelését idézi, miszerint a férfiak többsége mobilkészülékét használaton kívüli állapotban nem teszi el, s különösen akkor nem, ha a nemek aránya a csoportban a férfiak javára billen el (azaz nó a versenytársak száma). A szerző azt szúri le, hogy a mobiltelefon a gazdagság szimbólumaként (hasonlóan más, nagyobb értékû tárgyakhoz) a potenciális társak vonzásának eszköze is lett.

Nicola Green is - bár nem biológiai, hanem szociológiai megközelítést alkalmazva - az újfajta kommunikációs kapcsolatoknak a közösségi viszonyrendszerekre gyakorolt hatásait tárgyalja, viszont ố a társadalom gyökeres újraszerveződését hangsúlyozza, melyet elsôsorban - az erôsen személyhez kötődő - mobil technológiáknak tulajdonít. A kapcsolatok alapvetően a közvetített információ jelentésével, az egyén identitásával és a térben való elhelyezkedésével kapcsolatos bizonytalanságok köré szerveződnek. E kétértelmúségeket egyrészt a névtelenség lehetősége generálja, ad absurdum annak lehetősége, hogy virtuális identitásokat hozzunk létre, másrészt az a tény, hogy a szubjektum elektronikus adatnyomok formájában valóban megduplázódik. A jelenség másik oldala, hogy az egyének láthatóbbá és számonkérhetôbbé, tehát kiszolgáltatottabbá váltak - egyfelől a mobiltelefonok által létrehozott (potenciálisan) állandó kommunikációs összeköttetés révén, másrészt a technológia azon tulajdonsága által, hogy képes információt generálni és rögzíteni a felhasználóról. A láthatóságnak nemcsak a személyközi kapcsolatok tekintetében van jelentôsége, hanem befolyásolja a modern jogi személyek és a szubjektum közötti relációkat is: a szervezetek megfigyelik és ellenôrzik az egyént a róla szerzett tudás révén. Green arra is figyelmeztet, hogy mind az interperszonális viszonyok, mind az egyén-állam és az egyén-cégek közötti kapcsolatok reciprocitáson alapulnak: az információkért cserébe az állam biztosítja a szubjektum védelmét és kodifikálja kapcsolatrendszereit, a cégek pedig árucikkeiket és szolgáltatásaikat nyújtják. (v.ö.: André Vitalis: Kamerás megfigyelés, biztonság és szabadság, In.: Információs Társadalom 2002 1. sz,) Amint az előbbiekből kiderül, a kommunikációs folyamatban mindkét fél számára jelentkeznek kockázatok: az egyén oldalán adatainak nyomonkövethetôségérốl (s tegyük hoz- 
zá: felhasználhatóságáról) van szó, a szervezetek oldalán viszont azt kell figyelembe venni, hogy csupán információkat, s nem igazi tudást gyưjtenek a szubjektumról és annak motivációiról. Green szerint a bizonytalanság és kockázatok kölcsönös felvállalása miatt a kommunikáció alapvetố elemévé a bizalom válik, így a közösségi kapcsolatokat bizalmi hálózatokként értelmezi.

A fent ismertetett gondolkodók - talán Dunbart kivéve - ahhoz a nézethez csatlakoznak, miszerint a modern kommunikációs technológiák elterjedése - hiszen átformálta a kognitív folyamatokat és a társas kapcsolatrendszereket - kulturális-evolúciós váltáshoz vezet. Ezt a megközelítést alátámasztja, hogy az emberiség történetében minden új közlésmód - a beszéd, az írásbeliség és a könyvnyomtatás - megjelenése paradigmaváltást idézett elő. A korunkat jellemzô fordulat azért is nevezhetô egyedinek, mert a tudomány azonnal felismerte és értelmezni kezdte. A ma tudósai persze könnyebb helyzetben vannak, mint az előzô korokéi: az információs korszak változásai nem emberöltôk, hanem évek-évtizedek alatt bontakoztak ki, sokkal élesebb tehát a cezúra. A kutató munkáját az is segítheti, hogy még emlékeiben őrzi az előző, mobiltelefon és Internet nélküli idôszakot is, s az új jelenségeket személyes élményként tapasztalja meg.

A 21. sæázadi kommunikáció új útjai konferencia előadói rávilágítottak az evolúciós váltás számos fontos elemére: az információtovábbítás közvetettségére, a virtualitásra, az idő és a tér eddigi rendjének felborulására, a készségek szerepének megnövekedésére, a képi gondolkodás térnyerésére és a másodlagos, adat-szubjektumok kialakulására.

\section{JEGYZETEK}

${ }^{1}$ A 21. század kommunikációja címet viselô kutatásról a www.fil.hu/mobil webhely nyújt teljes képet.

2 Nicola Green: A közösség újrameghatározása: magánszféra és számonkérhetőség; Herbert Hrachovec: Közvetített jelenlét; Robin Dunbar: Vannak-e az e-világnak kognitív korlátai?; Pléh Cisaba: A kommunikációs mintázatok és a kognitív architektúrák kapcsolata; Nyíri Kristóf: Képi jelentés és mobil kommunikáció

3 Donald, Merlin, (2001): Az emberi gondolkodás keletkezése, Budapest, Osiris Donald, Merlin, (2001): A mind so rare. The evolution of human consciousness, New York-London, W.W. Norton \& Company

4 Nyíri Kristóf, (1992): A hagyomány filozófiája, Budapest, T-Twins 